\title{
Structural Assessment and Restoration of the NeelagiriMaha Seya in Ampara, Sri Lanka
}

Wijerathna Haluge Tharindu Sameera Wijerathna, Ranasinghe Arachchige Madhusha Priyadarshani Ranasinghe, Pallaha Athawudagedara Kamal Karunananda*

Department of Civil Engineering, The Open University of Sri Lanka, Nawala, Sri Lanka

\section{Abstract}

NeelagiriMaha Seya, constructed in the $2^{\text {nd }}$ Century BC, is a colossal ruined stupa, situated in the woods of the Lahugala wildlife sanctuary in the Ampara district of the Eastern province, Sri Lanka. The stupa has a circumference of $182 \mathrm{~m}$ (600') and a height of 22.6 $\mathrm{m}\left(74^{\prime}\right)$. Presently, one side of the stupa has collapsed and some vertical cracks are visible on the eastern side of lower dome section of the stupa. Therefore, it is essential to carry out proper investigation on the current condition of the stupa before undertaking any major restoration work to restore the stupa to its original height. With this objective, a series of experimental testing and numerical modeling were performed. The foundation of the stupa was assessed using the Ground Penetration Radar (GPR) method. According to the GPR measurements, the stupa spreads $2.87 \mathrm{~m}$ away from the basal rings

* Corresponding should be addressed to Dr. P. A. K. Karunananda, Department of Civil Engineering, The Open University of Sri Lanka, Nawala, Sri Lanka

Email: pakar@ou.ac.lk

(D)https://orcid.org/0000-0001-9581-7440

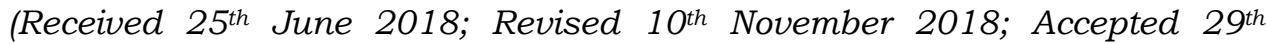
November 2018) (C) OUSL

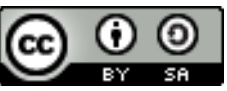

This article is published under the Creative Commons Attribution-Share Alike 4.0 International License (CC-BY-SA). This license permits use, distribution and reproduction in any medium; provided it is licensed under the same terms and the original work is properly cited. 
to a depth of $3 \mathrm{~m}$ from the existing ground level. It is apparent from GPR data, there exists gravel type rock below $3 \mathrm{~m}$ level from the existing ground and the stupa rests on matt gravel layer. Material properties of the ancient bricks of the stupa were evaluated with adequate laboratory testing. Test results showed that ancient bricks of the Neelagiri stupa have higher capacity than the modern bricks. Numerical analysis of the stupa was carried out using the general finite element software package SAP2000 to assess the stresses developed in the stupa due to its self-weight. The results showed that the stresses developed within the existing stupa due to its self-weight were well below the compressive strength and the tensile strength of the ancient bricks. Further, the study suggests two alternative shapes (bubble and paddy heap shapes) for completing the stupa restoration. A suitable shape is proposed for the restoration and the different restoration options have been analyzed with respect to structural performance along with the existing conditions.

Key words: Stupas, Ancient Bricks, Mechanical Properties, Ground Penetration Radar, Finite Element Analysis

\section{Introduction}

Ancient stupas in Sri Lanka are solid structures, mostly composed of burnt clay bricks. Construction of stupas began in the $3^{\text {rd }}$ Century $\mathrm{BCE}$ and lasted until the $13^{\text {th }}$ Century CE. During this period, some stupas, such as the Jethavana attained gigantic proportions, making them the largest brick structures in the world (Ranaweera 1998). At the turn of the 19th Century, all the ancient stupas were in ruins, covered with thick vegetation. Initial rehabilitation of these stupas was attempted in haphazard ways, but presently the modern civil engineering principles along with archaeological heritage management are being applied for the conservation and restoration of these historical structures (Ranaweera \& Silva 2006; Silva 2002).

NeelagiriMaha Seya, constructed in the $2^{\text {nd }}$ Century BCE, is a colossal ruined stupa, situated in the woods of the Lahugala wildlife sanctuary of the Ampara district of the Eastern province. The stupa had been abandoned for nearly 1200 years. It has a circumference of $182 \mathrm{~m} \mathrm{(600')} \mathrm{and} \mathrm{a} \mathrm{height} \mathrm{of} 22.6 \mathrm{~m}$ (74') in its current status. Some restoration work was started in 1960 and later on had to be abandoned due to the civil war. The structure has been opened only after 2010 and restoration work was begun in 2011. Fig. 1(a) shows a view at its current status. 

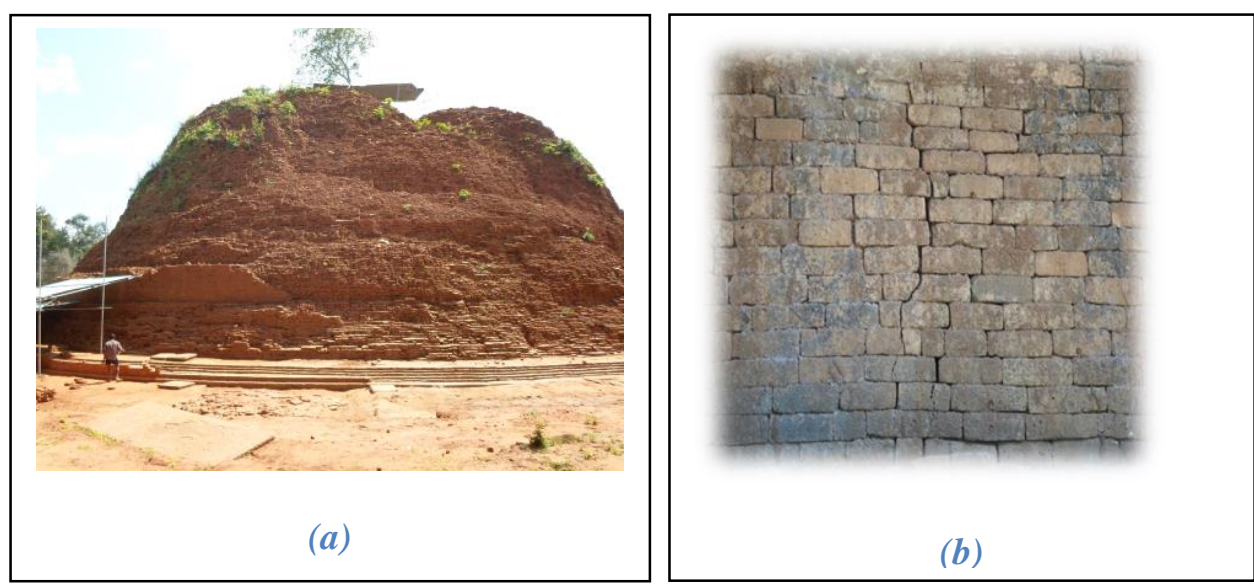

Figure 1. Two views of the stupa: (a) after the removal of vegetation cover (b) a crack formed in the dome of the stupa

One side of the stupa has collapsed and some vertical cracks are presently visible on lower dome section of the stupa, as shown in Fig. 1 (b). Therefore, it is essential to carry out proper investigation on the current condition of the stupa before any major restoration work. This paper aims to investigate the present condition of the stupa, with specific focus on experimental testing on construction materials used in the stupa construction followed by numerical modeling of the stupa to aid its restoration work.

\section{Methodology}

Site visits and information obtained from the literature review revealed that the main construction material used for the stupa is burnt clay bricks. Old bricks used for the construction of the stupa by the ancient engineers differ from modern bricks in sizes. In this regard, there were four different sizes of bricks which are comparatively larger than modern engineering bricks. The details of these four brick types are shown in Table 1. A close analysis revealed that these brick types were used in random without a distinct pattern. However, the usage of type IV bricks was rare. The mortar layers in between bricks were similar to the other stupas in Sri Lanka. Further, brick layering did not follow specific rules. 
Table 1. Dimensions of different types of bricks

\begin{tabular}{|c|c|c|c|c|}
\hline $\begin{array}{l}\text { Brick } \\
\text { Type }\end{array}$ & $\begin{array}{c}\text { Weight } \\
\text { (kg) }\end{array}$ & $\begin{array}{l}\text { Length } \\
\text { (L)/(mm) }\end{array}$ & $\begin{array}{c}\text { Breadth } \\
\text { (W)/(mm) }\end{array}$ & $\begin{array}{l}\text { Thickness } \\
\text { (H)/(mm) }\end{array}$ \\
\hline I & 8.709 & 290 & 220 & 85 \\
\hline II & 9.881 & 420 & 220 & 78 \\
\hline III & 9.461 & 295 & 260 & 83 \\
\hline IV & 8.182 & 235 & 165 & 113 \\
\hline
\end{tabular}

\section{Experimental Testing of Bricks}

The mechanical properties of brick samples were determined using non-destructive testing methods. In this context, portable ultrasonic non-destructive digital indicating tester (PUNDIT) instrument and resonance frequency instrument were used. In PUNDIT instrument, determination of elastic modulus is based on the pulse velocity. Table 2 shows the results obtained on pulse velocity. Thereafter, elastic modulus and the Poisson's ratio were determined for four brick types as shown in Table 2 .

Table 2. Measurements of PUNDIT instrument for different types of bricks

\begin{tabular}{|c|c|c|c|c|c|}
\hline $\begin{array}{l}\text { Brick } \\
\text { Type }\end{array}$ & $\begin{array}{c}\text { Path } \\
\text { Length } \\
\text { (L)/(in) }\end{array}$ & $\begin{array}{c}\text { Transit } \\
\text { Time } \\
\text { ( } \mathrm{s})\end{array}$ & $\begin{array}{c}\text { Pulse } \\
\text { Velocity } \\
\text { (V)km/s }\end{array}$ & $\begin{array}{c}\text { Elastic } \\
\text { Modulus } \\
\left(\mathrm{kN} / \mathbf{m m}^{2}\right)\end{array}$ & $\begin{array}{c}\text { Poisson's } \\
\text { Ratio }\end{array}$ \\
\hline I & 4.25 & 63.80 & 1.69 & 10.05 & 0.25 \\
\hline II & 4.25 & 54.85 & 1.97 & 11.00 & 0.24 \\
\hline III & 4.25 & 55.47 & 1.98 & 11.00 & 0.20 \\
\hline IV & 6.25 & 99.25 & 1.6 & 9.50 & 0.25 \\
\hline
\end{tabular}

Compressive strength of bricks was measured through a compressive testing machine. Water absorption testing of bricks was done after immersing brick samples for 24 hours and measuring the weight gain. Dry density of bricks was measured using oven dried brick samples. The results obtained are given in Table 3. 
Table 3. Mechanical properties of different types of bricks

\begin{tabular}{llll}
\hline Brick Type & $\begin{array}{l}\text { Water } \\
\text { Absorption } \\
(\%)\end{array}$ & $\begin{array}{l}\text { Dry Density/ } \\
\left(\mathbf{k g} / \mathbf{m}^{3}\right)\end{array}$ & $\begin{array}{l}\text { Compressive } \\
\text { Strength } \\
(\mathbf{M P a})\end{array}$ \\
\hline I & 8 & 1615.74 & 3.003 \\
\hline II & 9.1 & 1315.98 & 8.581 \\
\hline III & 9.6 & 1423.97 & 9.654 \\
\hline IV & 9.6 & 1703.80 & 4.291 \\
\hline
\end{tabular}

Table 4 shows the elastic modulus and Poisson's ratio of ancient bricks from other stupas with the Neelagiri stupa. The compressive strength of bricks from the Neelagiri stupa is almost five times as strong as modern bricks.

Table 4. Comparison of mechanical properties of different stupas

\begin{tabular}{lcc}
\hline \multicolumn{1}{c}{ Brick Type } & $\begin{array}{c}\text { Elastic Modulus } \\
\left(\mathbf{k N} / \mathbf{m m}^{\mathbf{2}}\right)\end{array}$ & $\begin{array}{c}\text { Poisson's } \\
\text { Ratio }\end{array}$ \\
\hline $\begin{array}{l}\text { Jethavanaseya } \\
\text { (Ranaweera 1998) }\end{array}$ & 4.5 & 0.25 \\
\hline $\begin{array}{l}\text { Sandagiriseya } \\
\text { (Ranaweera 1998) }\end{array}$ & 9.79 & 0.27 \\
\hline Neelagiriseya & 10.53 & 0.24 \\
\hline Modern brick & 1.92 & 0.21 \\
\hline
\end{tabular}

\section{Ground Penetration Radar}

The purpose of ground penetration radar is to determine the foundation work of the stupa. Twelve observation lines were surveyed around the Neelagiri stupa, from the basal ring, about $30 \mathrm{~m}$ spanning as shown in Fig. 2. In lines 1, 2, 3 and 4, $200 \mathrm{MHz}$ antenna was used while lines a, b, c, d, e, f, g and h, $500 \mathrm{MHz}$ antenna was used. The procedure of Ground Penetration Radar use is given by Dojack, 2012. 


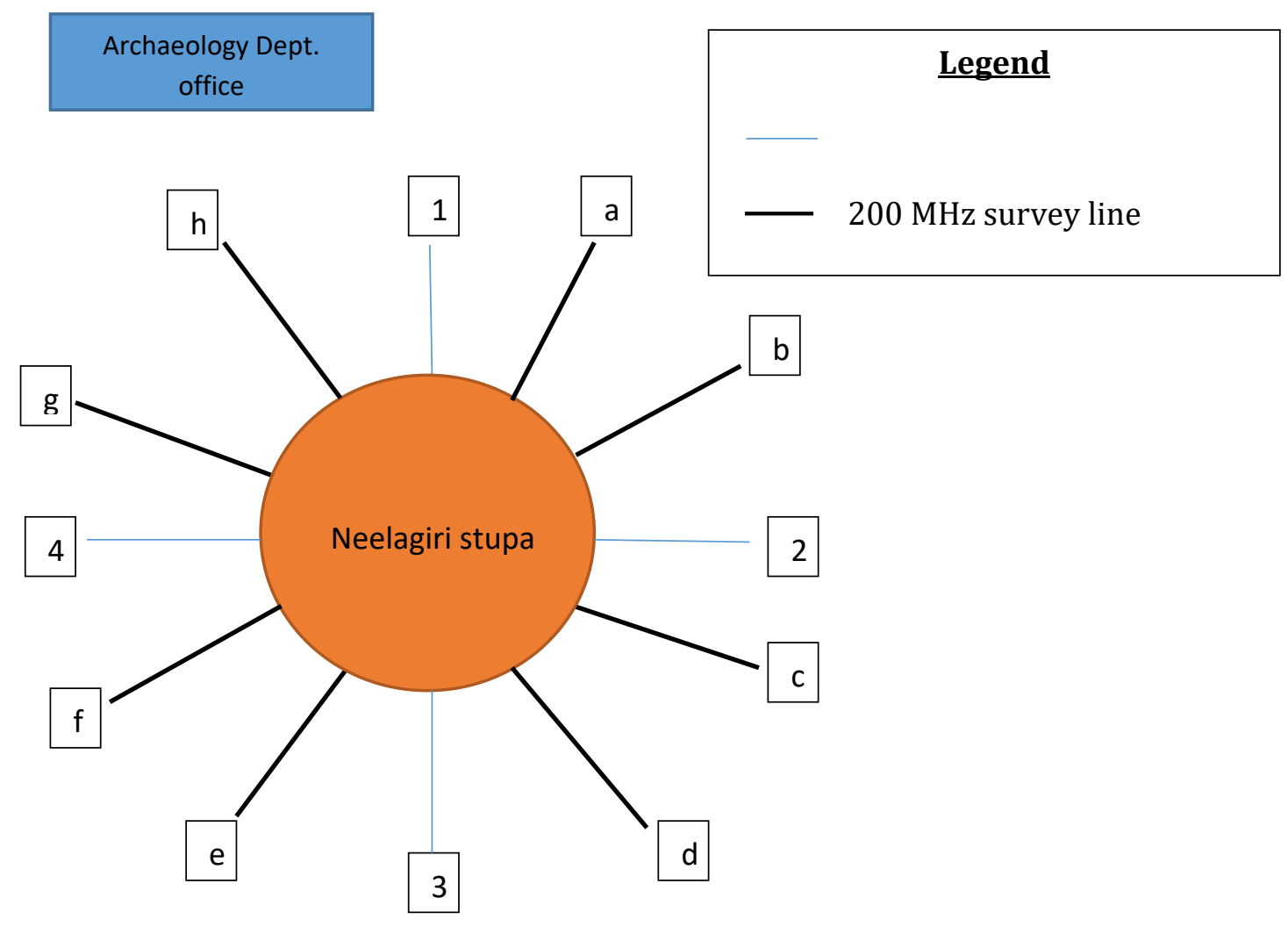

Figure 2. Layout of survey lines for ground penetration radar

\section{GPR Results}

Figures 3 and 4 show the results of GPR machine for each selected line. However, it is difficult to identify the underground data straight from frequency data. Therefore, the EKKO View Deluxe software was used to analyse reflection data removing unnecessary noise waves. Fig. 3 shows $200 \mathrm{MHz}$ survey line results of GPR machine. $200 \mathrm{MHz}$ GPR is capable of surveying the depth of $5 \mathrm{~m}$ to $10 \mathrm{~m}$. Fig. 4 shows the $500 \mathrm{MHz}$ survey line results of GPR machine. $500 \mathrm{MHz}$ GPR is capable of surveying of $0 \mathrm{~m}$ to $5 \mathrm{~m}$ depth. It is more suitable for 2.5 m depth. 


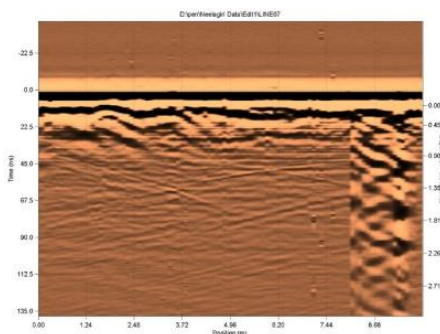

Line 1

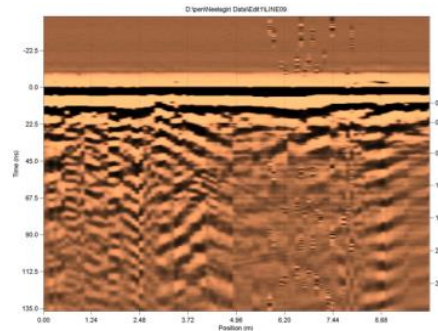

Line 3
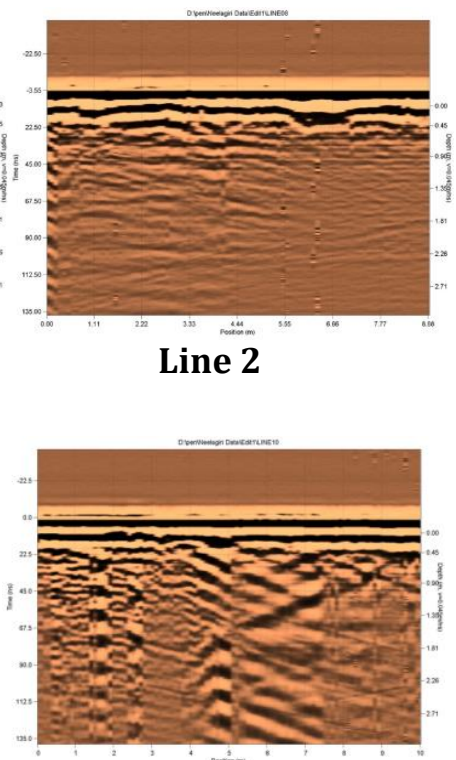

Line 4

Figure 3. The $200 \mathrm{MHz}$ survey line results of GPR machine

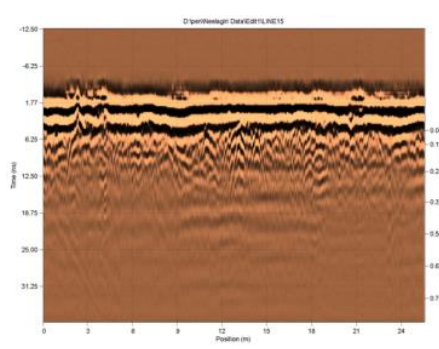

Line a

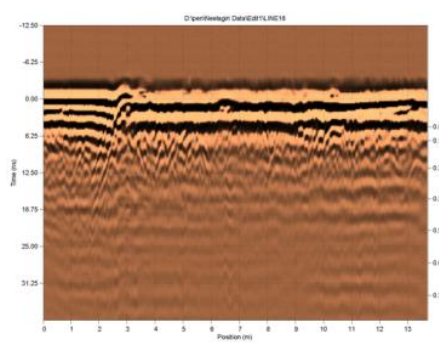

Line d

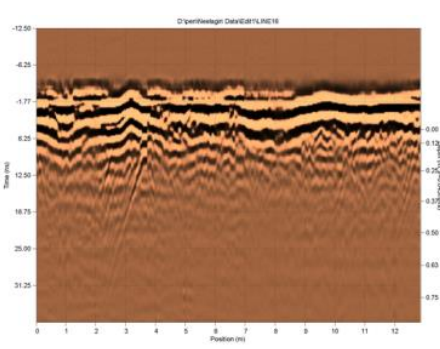

Line b

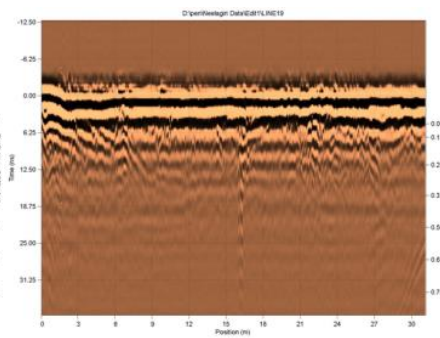

Line e

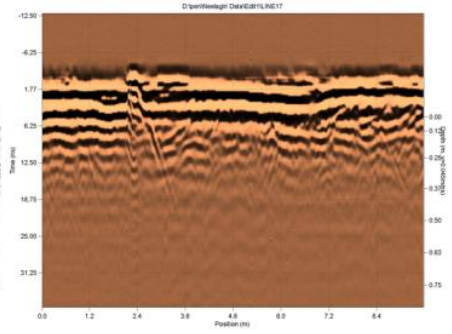

Line c

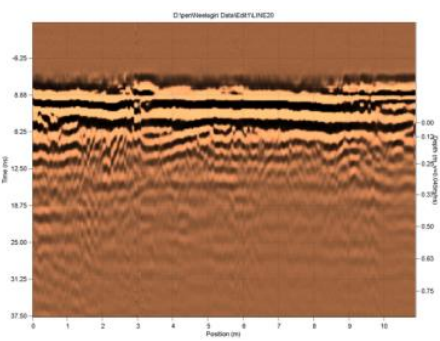

Line $f$ 


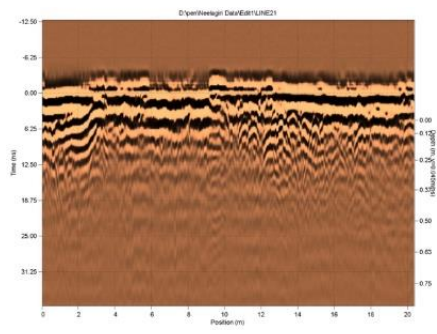

Line $g$

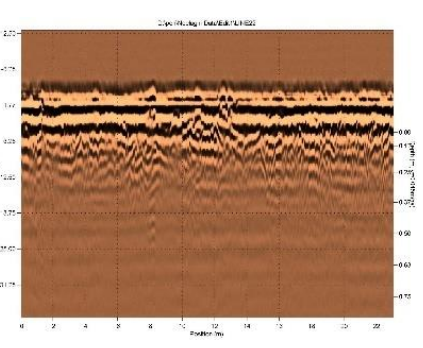

Line $h$

Figure 4. The $500 \mathrm{MHz}$ survey line results of GPR machine

\section{The Analysis of GPR Data}

The obtained results are shown in Figures 5, 6 and 7.

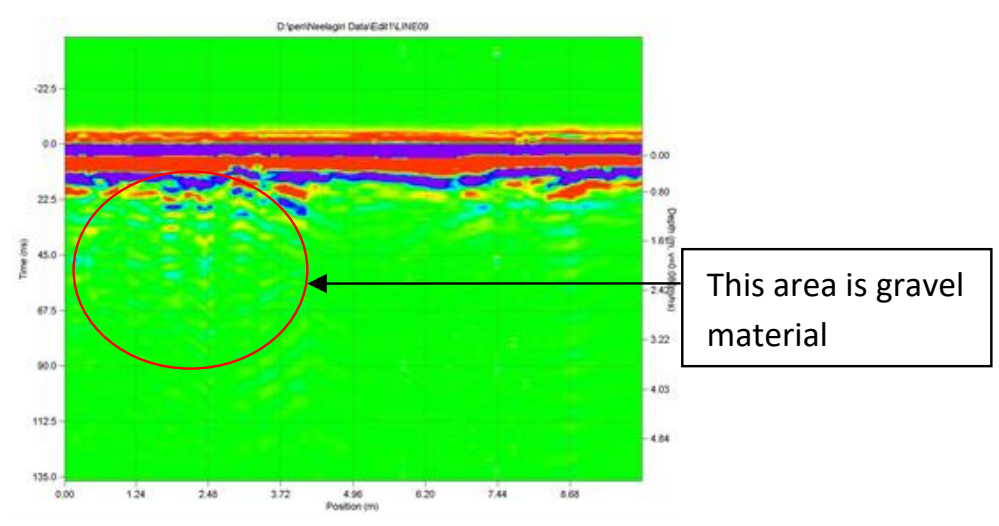

Figure 5. The analyzed GPR $200 \mathrm{MHz}$ survey line 1 around the stupa

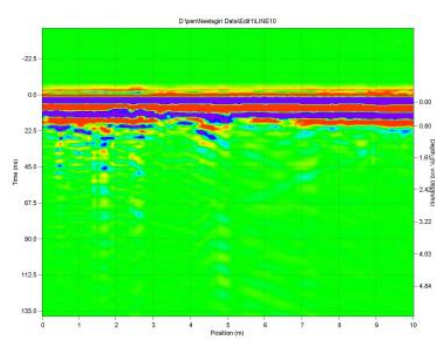

Line 1

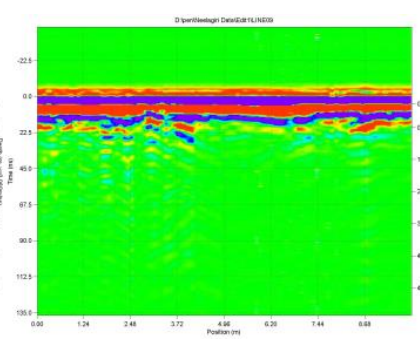

Line 2

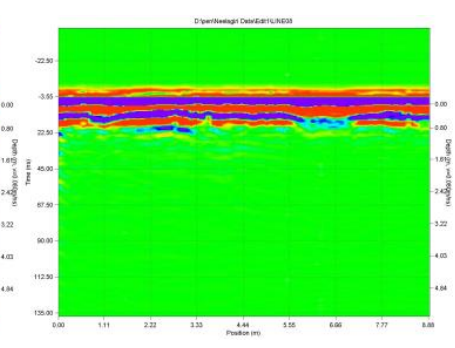

Line 3 


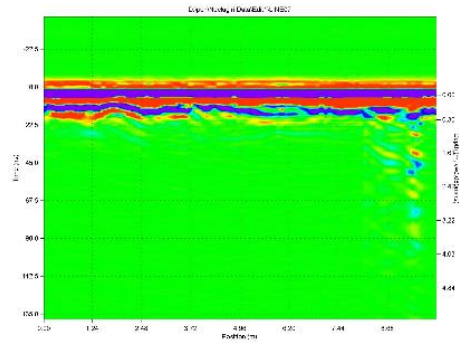

\section{Line 4}

Figures 6. The all-analyzed GPR $200 \mathrm{MHz}$ survey lines around thestupa.

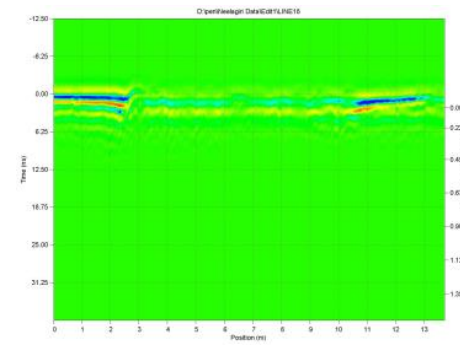

Line a

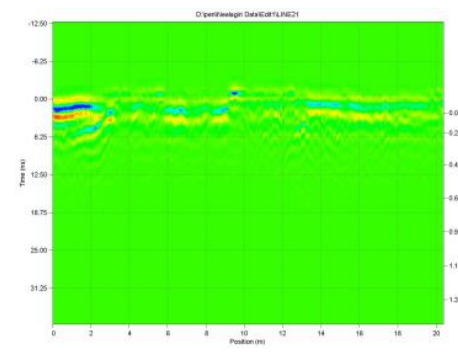

Line d

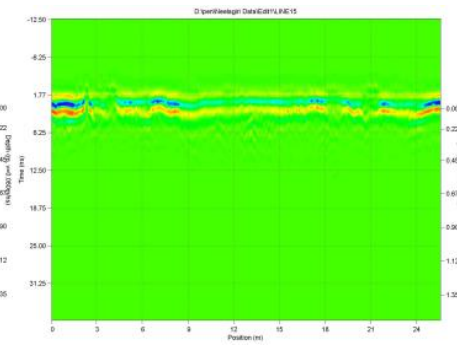

Line b

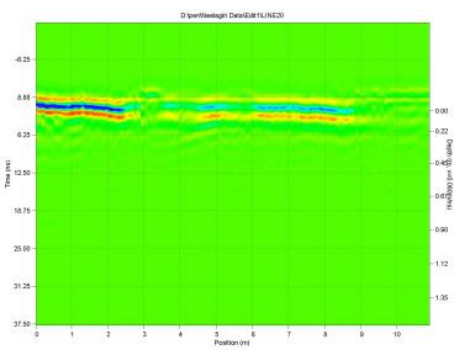

Line e

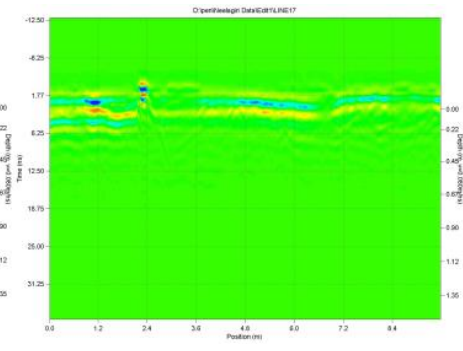

Line c

Figures 7. The all-analyzed GPR $500 \mathrm{MHz}$ survey lines around thestupa

The data collected clearly showed the foundation structure of the stupa. The resulting survey information facilitated the identification of the type of materials used for the foundation of the stupa. The foundation of the stupa is spread around for the average distance of $2.87 \mathrm{~m}$ from basal rings (Fig. 8). According to the survey (based on the velocity of the radar through materials), it is apparent that there 
is a clay wet soil at the top layer and gravel materials at the bottom layer up to the bed rock. This gravel layer is around $3 \mathrm{~m}$ deep.

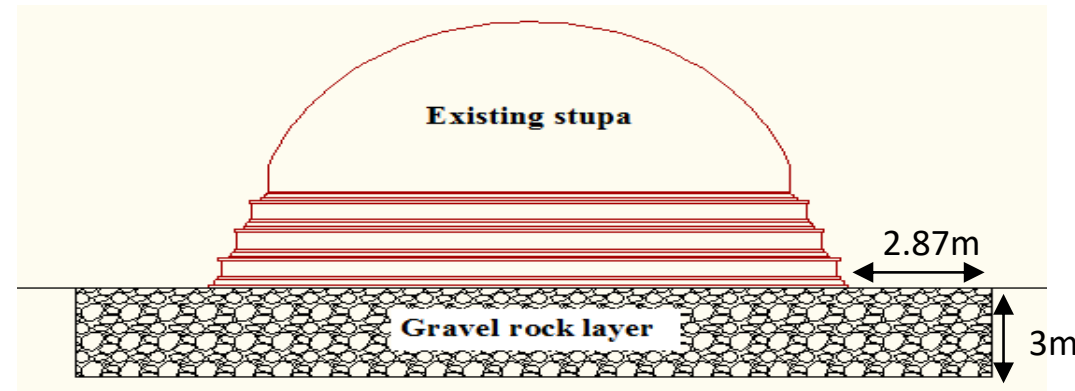

Figure 8. Mapping the extent and location of thefoundation around the stupa

The observations of results do not indicate the deepest point in the bed rock because it was difficult to take the readings in continuously due to the presence of water locations on the survey lines.

\section{Full Geometry of the Stupa}

During excavation, small stupa structures were found in the site. Those stupas may symbolize the original shape of the stupa. When those stupas were examined, it was identified that the bubble shape and the paddy-heap shape are more common than the other shapes. However, there is no information about the actual shape of the ancient Neelagiri stupa. Therefore, bubble and paddy-heap shapes were considered for the restoration works.

\section{Height Proportion of the Stupa}

The present Neelagiri stupa is only about one third of its complete height according to the studies of the archaeologists (Somadeva 2012). Therefore, more than about two third area of the collapsed stupa is to be restored with a complete dome and the superstructure. Some of the other ancient stupas were closely examined to identify the height of elements with respect to the diameter and the shape of the dome. Therefore, in the suggested restoration design, the height was compared with Mirisawetiya (bubble shape) and Jethavana(paddy-heap shape) stupas according to the diameter of the Neelagiri stupa and its shape. 
Table 5. Height details of Jethavana and Mirisawetiya stupa

\begin{tabular}{lll}
\hline Components & $\begin{array}{l}\text { Jethavana* } \\
\text { (paddy-heap } \\
\text { shape) }(\mathrm{m})\end{array}$ & $\begin{array}{c}\text { Mirisawetiya** } \\
\text { (bubble shape) } \\
(\mathrm{m})\end{array}$ \\
\hline Diameter & 102 & 53.5 \\
\hline Three pesavas & 3.69 & 3.29 \\
\hline Dome & 41.76 & 23.99 \\
\hline Square chamber & 11.79 & 6.86 \\
\hline Dewathakotuwa & 9.45 & 4.42 \\
\hline Koth karalla & 22.25 & 18.59 \\
\hline $\begin{array}{l}\text { Total height without } \\
\text { kotha }\end{array}$ & 88.94 & 57.15 \\
*The dimensions are according to the source (Gamalath 1997) & \\
**The dimensions are according to the drawing, Dept. of \\
$\begin{array}{l}\text { Archaeology } \\
\text { The }\end{array}$
\end{tabular}

Table 6. Height details of the Neelagiri stupa alongside the Jethavana and Mirisawetiya

\begin{tabular}{|c|c|c|}
\hline Components & $\begin{array}{l}\text { Height according } \\
\text { to Jethavana } \\
\text { (paddy-heap } \\
\text { shape ) } \\
\text { (m) }\end{array}$ & $\begin{array}{l}\text { Height according } \\
\text { to Mirisawetiya } \\
\text { (bubble shape) } \\
\text { (m) }\end{array}$ \\
\hline Three pesavas & 2.1 & 3.6 \\
\hline Dome & 23.7 & 26.0 \\
\hline Square chamber & 6.7 & 7.4 \\
\hline Dewathakotuwa & 5.4 & 4.8 \\
\hline Koth karalla & 12.7 & 20.1 \\
\hline $\begin{array}{l}\text { Total height without } \\
\text { kotha }\end{array}$ & 50.6 & 62.0 \\
\hline
\end{tabular}

According to the diameter of Neelagiri stupa, the above height details were calculated using the Jethavana and Mirisawetiya stupas as in Table 6. Based on the dimensions obtained, two alternative models 
were developed with two different shapes considering the shape as bubble and paddy-heap. The structure was modeled as solid brick structure. The proposed two alternatives are as follows:

a) Alternative I : Bubble-shape solid brick structure [Figure 9 (a)]

b) Alternative II :Paddy-heap shape solid brick structure [Figure 9 (b)]

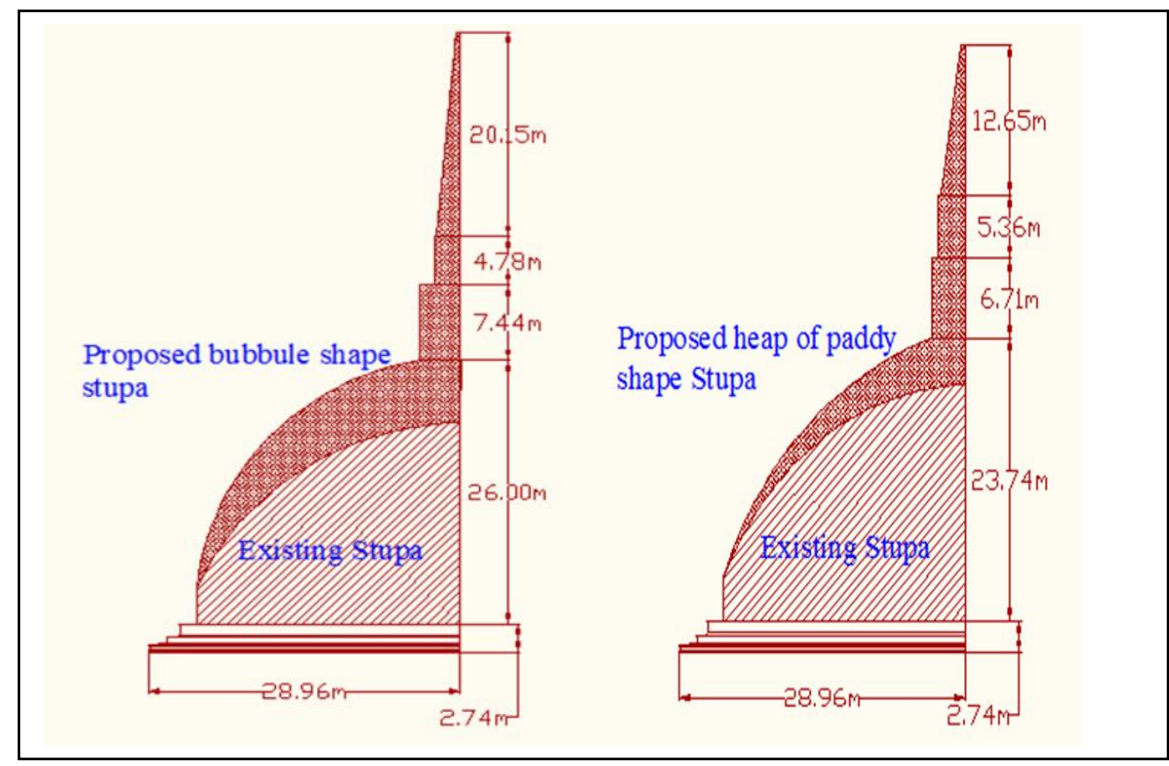

Figure 9. (a) Alternative I and (b) Alternative II

The proposed construction could be achieved through old bricks or new bricks. Therefore, there are four different options which have to be analyzed separately in addition to the existing stupa.

\section{Finite Element Analysis}

\section{Materials Properties for Finite Element Models}

Among the different restoration options suggested for the Neelagiri stupa which were discussed in detail in above, a solid brick structure is proposed to complete the existing stupa. The finite element analysis of this solid superstructure is to be carried out by using the material properties of presently available good quality wire-cut bricks as well as old bricks. The material properties, elastic modulus, compressive strength and tensile strength of these bricks were obtained by the same test methods described for the existing old brick in above section. Table 7 shows the results obtained for the elastic modulus, 
and compressive strength of the wire-cut brick respectively. These mechanical properties were used during finite element modeling.

Table 7. Material properties of modern and Neelagiri stupa bricks

\begin{tabular}{lll}
\hline Properties & $\begin{array}{l}\text { Modern } \\
\text { bricks }\end{array}$ & $\begin{array}{l}\text { Neelagiri } \\
\text { bricks }\end{array}$ \\
\hline Dry density $\left(\mathrm{kNm}^{-3}\right)$ & 17.0 & 17.46 \\
\hline Wet density $\left(\mathrm{kNm}^{-3}\right)$ & 19.6 & 19.04 \\
\hline Elastic modulus $(\mathrm{GPa})$ & 2.3 & 10.0 \\
\hline Poisson's ratio & 0.21 & 0.24 \\
\hline $\begin{array}{l}\text { Compressive strength } \\
(\mathrm{MPa})\end{array}$ & 3.60 & 6.38 \\
\hline Tensile strength $(\mathrm{MPa})^{*}$ & 0.31 & $0.55^{*}$ \\
\hline Thermal coefficient & $5.5 \times 10^{-6}$ & $5.5 \times 10^{-6 *}$ \\
\hline
\end{tabular}

* Data extracted same era stupa (Yudaganawadagoba)

\section{Model used for the Analysis}

The stupa was analyzed using an axisymmetric model by considering a half of the stupa for each alternative. In this case, the stupa was considered to be symmetric about the vertical axis. The geometric models used in the analysis for each alternative are shown in Fig. 9 (a) and 9 (b) respectively. These two models were analyzed using SAP2000. The model was also analyzed for self-weight.

\section{Model 1 (Old Brick Work, Existing Condition)}

From the direct stress contours (Fig. 10a), it can be noted that under self-weight, the stupa experiences compressive stresses and it gradually increases from top to bottom. A compressive stress variation of $0 \mathrm{kPa}$ to $339 \mathrm{kPa}$ can be seen for the vertical stress in the stupa. Majority of the stresses are compressive. A tensile stress region can be noted in the basal rings area but the magnitudes of these tensile stresses are in the range of $0 \mathrm{kPa}$ to $304 \mathrm{kPa}$. There are no tensile stresses at the outer surface of the dome. A sudden decrease in stress can be seen at the edges of the basal rings. This behavior could be attributed to the fact that these places are sharp corners. A detailed analysis of stresses at each region of the stupa is given below. The maximum compressive stress occurs at the centre of the foundation level and has a magnitude of $339 \mathrm{kPa}$ almost 18 times 
less than the allowable compressive strength of Neelagiri stupa's old bricks which has a value of $6380 \mathrm{kPa}$.

The hoop stress contours (Fig. 10b) also show a majority of compressive stresses and they too tend to increase from top to bottom. As in other stress contours, a high concentration of stresses can be seen at sharp corners. The tensile hoop stresses can be noted at the top of the dome and basal rings areas and, the magnitudes of these tensile hoop stresses are in the range of $0 \mathrm{kPa}$ to $97 \mathrm{kPa}$. The highest tensile hoop stress occurs at the corner where the dome meets the basal rings.
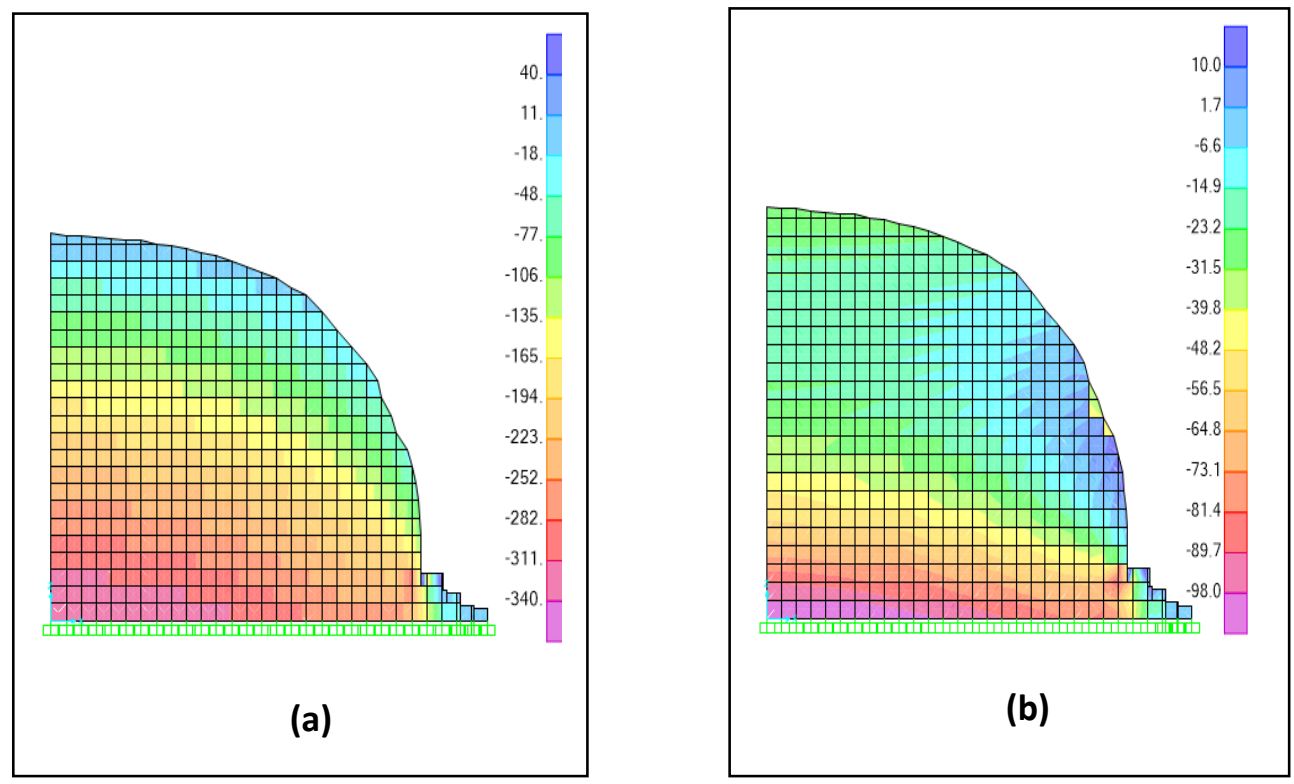

Figure 10. (a) vertical and (b) hoop stress contours $\left(\mathrm{kN} / \mathrm{m}^{2}\right)$ forthe existing stupa model

\section{Model 2(Old Brick Work, Proposed Bubble Shape)}

A compressive stress variation (Fig. 11a) of $0 \mathrm{kPa}$ to $428 \mathrm{kPacan}$ be seen for the vertical stress in the stupa. Majority of the stresses are compressive here. Another variation which can be noted is the stress concentration at the corners. Places where the square chamber meets the dome and where the dome meets the basal rings have high tensile stress concentrations compared to the surrounding areas. In the model created with the Neelagiri stupa bricks, it can be noted, that under self-weight most parts of the stupa are under compression and this compressive stress gradually increases from top to bottom. The 
maximum compressive stress occurs at the centre at the foundation level and its value is $428 \mathrm{kPa}$. At the outer surface of the dome no tensile stresses could be noted.

The hoop stress contours (Fig. 11b) also show a majority of compressive stresses and they too tend to increase from top to bottom. As in other stress contours a high concentration of stresses can be seen at sharp corners. The tensile hoop stress can be noted at the square chamber area, top of the dome and basal rings area and the magnitudes of these tensile hoop stresses are in the range of 0 $\mathrm{kPa}$ to $149 \mathrm{kPa}$. The highest tensile hoop stress occurs at the corner where the dome meets the basal rings.
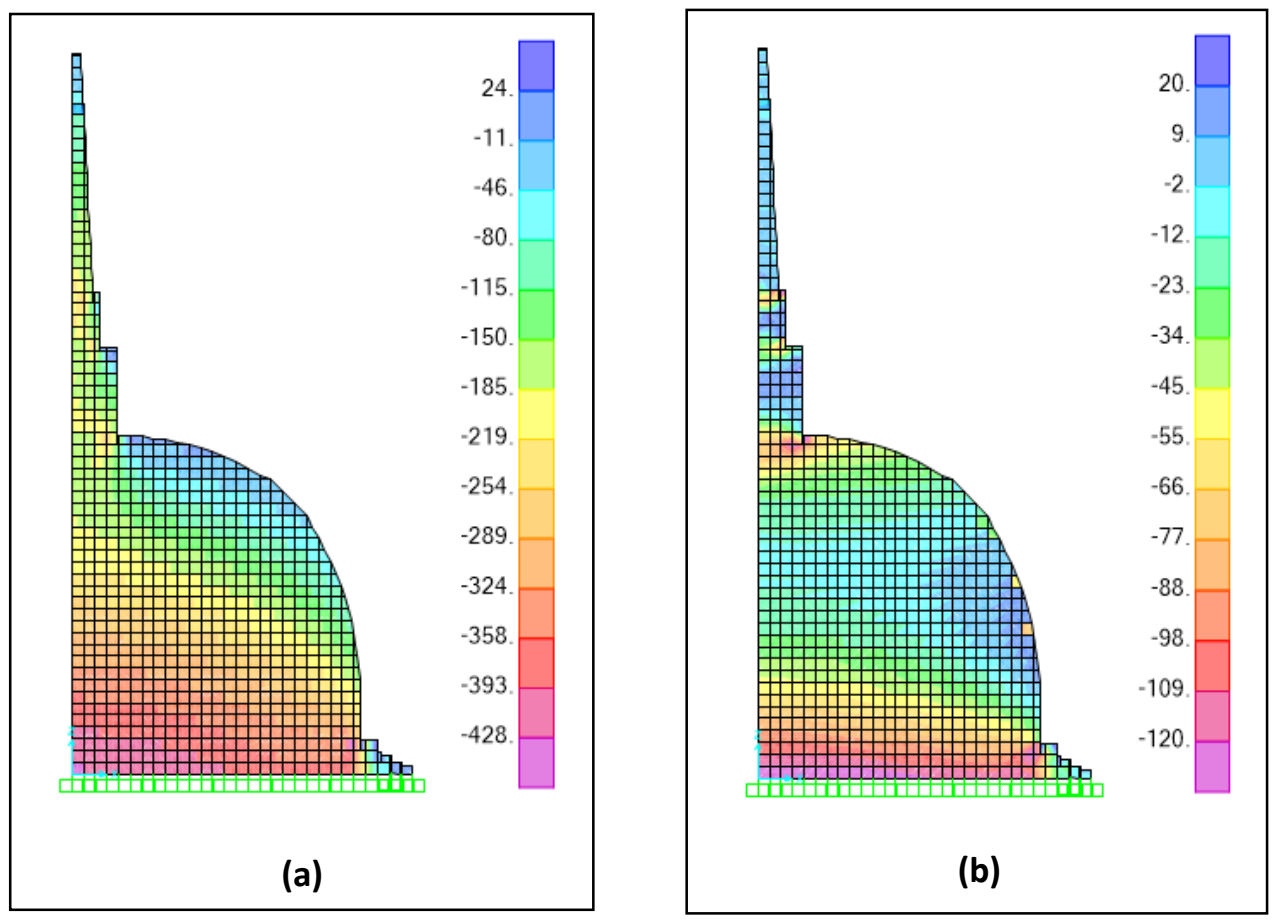

Figure 11. (a) vertical and (b) hoop stress contours $\left(\mathrm{kN} / \mathrm{m}^{2}\right)$ for the bubble shape model

\section{Model 3 (Old Brick Work, Proposed Paddy-Heap Shape)}

From the direct stress contours (Fig. 12a) it can be noted that, under self-weight, the stupa is under compression and this compressive stress gradually increases from top to bottom. A compressive stress variation of $0 \mathrm{kPa}$ to $373 \mathrm{kPa}$ can be seen for the vertical stress in the stupa. The highest tensile stress occurs at the corner where the dome 
W. H. T. S. Wijerathna, R. A. M. P. Ranasinghe \& P. A. K. Karunananda

meets the basal rings. The magnitudes of these tensile stresses are in the range of $0 \mathrm{kPa}$ to $341 \mathrm{kPa}$ which is smaller than the allowable tensile strength of old bricks.

The hoop stress contours (Fig. 12b) also show a majority of compressive stresses and they too tend to increase from top to bottom. As in other stress contours, a high concentration of stresses can be seen at sharp corners. The tensile hoop stress can be noted at the square chamber area, top of the dome and basal rings area. The magnitudes of these tensile hoop stresses are in the range of $0 \mathrm{kPa}$ to $116 \mathrm{kPa}$. The highest tensile hoop stresses can be noted at the edges of the basal rings.
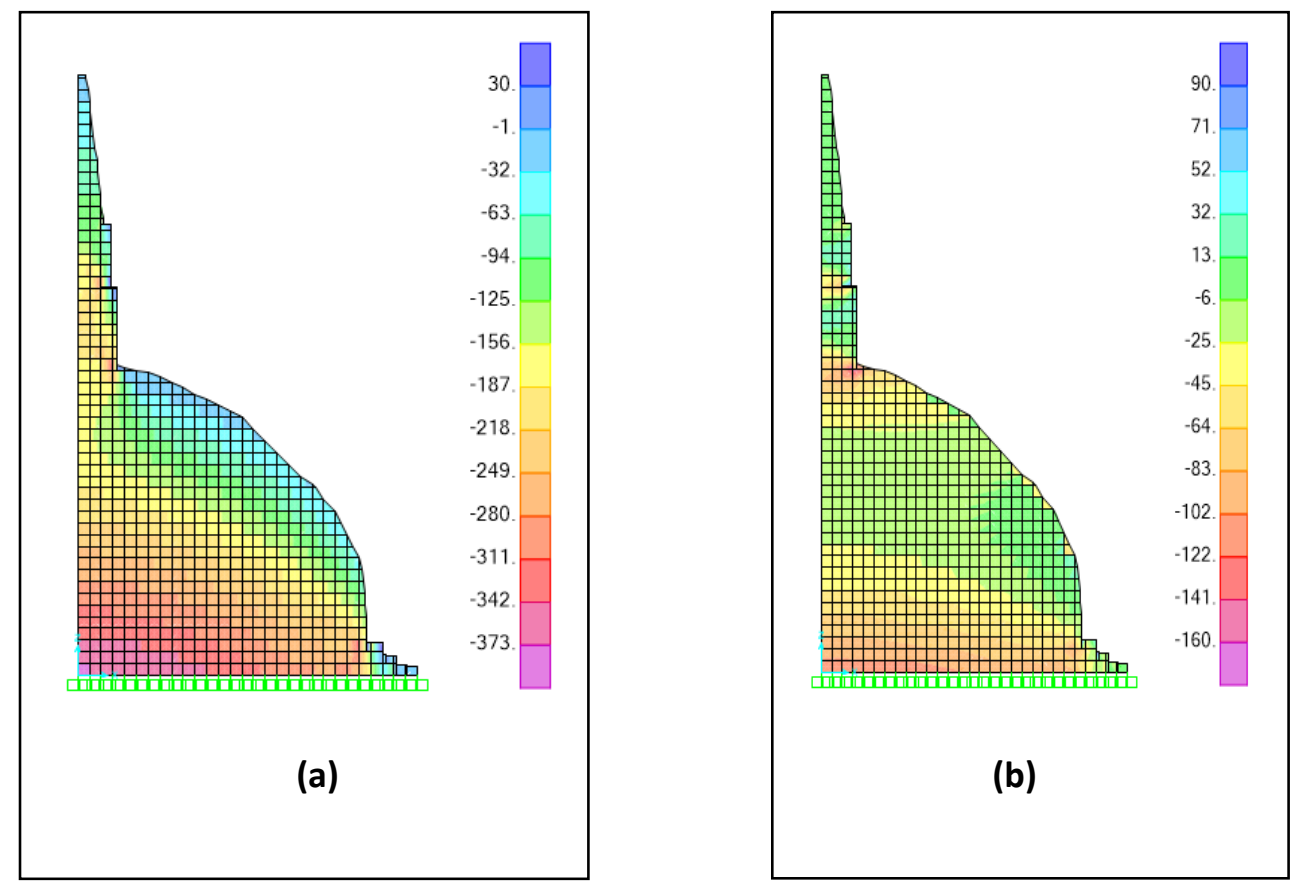

Figure 12. (a) vertical and (b) hoop stress contours $\left(\mathrm{kN} / \mathrm{m}^{2}\right)$ for the paddy- heap shape model

Model 4 (Old Brick and New Brick Work, Proposed BubbleShape) A compressive stress variation (Fig. 13a) of $0 \mathrm{kPa}$ to $435 \mathrm{kPa}$ can be seen for the vertical stress in the stupa. Majority of the stresses are compressive and a tensile stress region can be noted in the basal rings area. 
In this model, the existing area was created with old bricks and proposed area by new bricks. It can be noted that under self-weight most parts of the stupa is under compression and this compressive stress gradually increases from top to bottom. The maximum compressive stress occurs at the centre of the foundation level and its value is $435 \mathrm{kPa}$. At the outer surface of the dome no tensile stresses occur and tensile stresses can be noted in the areas where dome meets the basal rings area. Another variation which can be noted is the stress concentrations at the corners. Places where the square chamber meets the dome and where the dome meets the basal rings have a high compressive stress concentration compared to the surrounding areas. A sudden decrease in stress can be seen at the edges of the basal rings. This behaviour could be attributed to the fact that these places are sharp corners.

The hoop stress contours (Fig. 13b) also show a majority of compressive stresses and they too tend to increase from top to bottom. As like in other stress contours a high concentration of stresses can be seen at sharp corners. The tensile hoop stress can be noted at the square chamber area, top of the dome and basal rings area the magnitudes of these tensile hoop stresses range from $0 \mathrm{kPa}$ to $34 \mathrm{kPa}$. The highest tensile hoop stress occurs at the corner where the basal rings are located. 

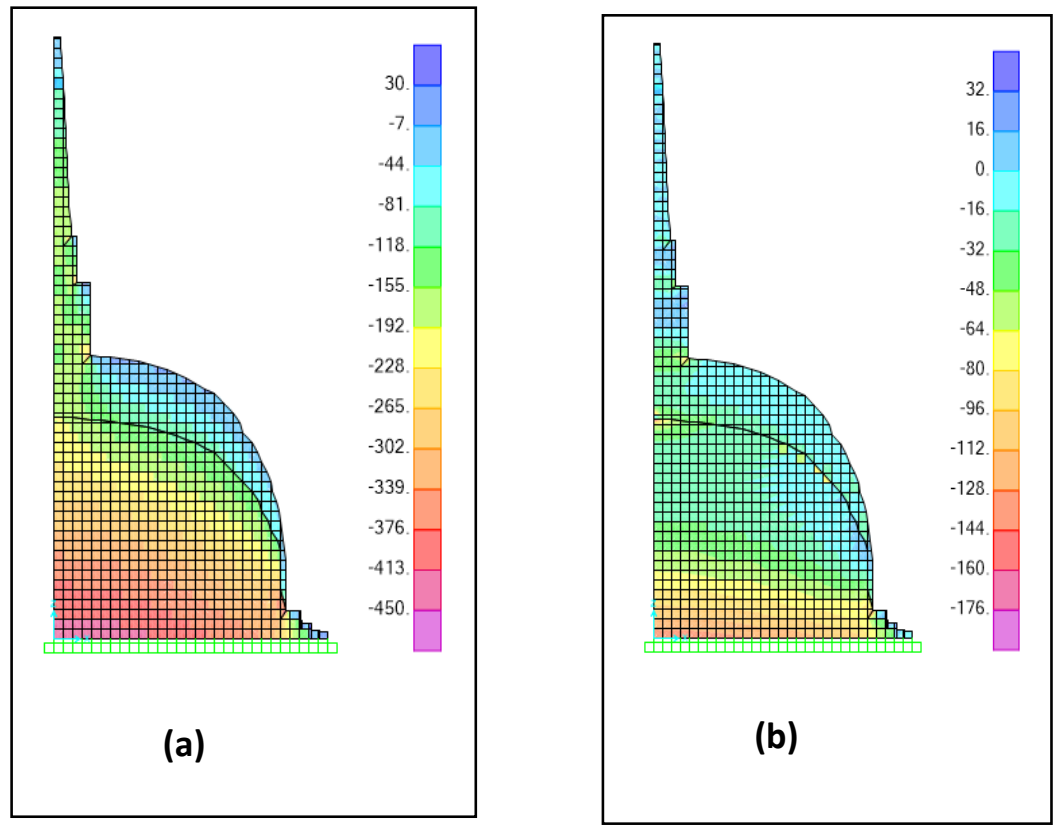

Figure 13. (a) vertical and (b) hoop stress contours $\left(\mathrm{kN} / \mathrm{m}^{2}\right)$ for the bubble shape model

\section{Model 5/Old Brick and NewBrick Work, Proposed Paddy- HeapShape)}

From the direct stress contours (Fig. 14a), it can be noted that, under self-weight, the stupa is under compression and this compressive stress gradually increases from top to bottom. A compressive stress variation of $0 \mathrm{kPa}$ to $383 \mathrm{kPa}$ can be seen for the vertical stress in the stupa. Tensile stresses can be noted at the basal rings' edges and no tensile stress at the outer surface of the dome. The magnitudes of these tensile stresses are in the range of $0 \mathrm{kPa}$ to $184 \mathrm{kPa}$ and the allowable tensile stresses of old bricks is $550 \mathrm{kPa}$.

The hoop stress contours (Fig. 14b) also show a majority of compressive stresses and they too tend to increase from top to bottom. As in other stress contours a high concentration of stresses can be seen at sharp corners. The tensile hoop stress can be noted at the square chamber area, dome area and basal rings area the magnitudes of these tensile hoop stresses are in the range of $0 \mathrm{kPa}$ to $259 \mathrm{kPa}$. The highest tensile hoop stress occurs at the centre of the dome where the old and new brick intermediate surface. 

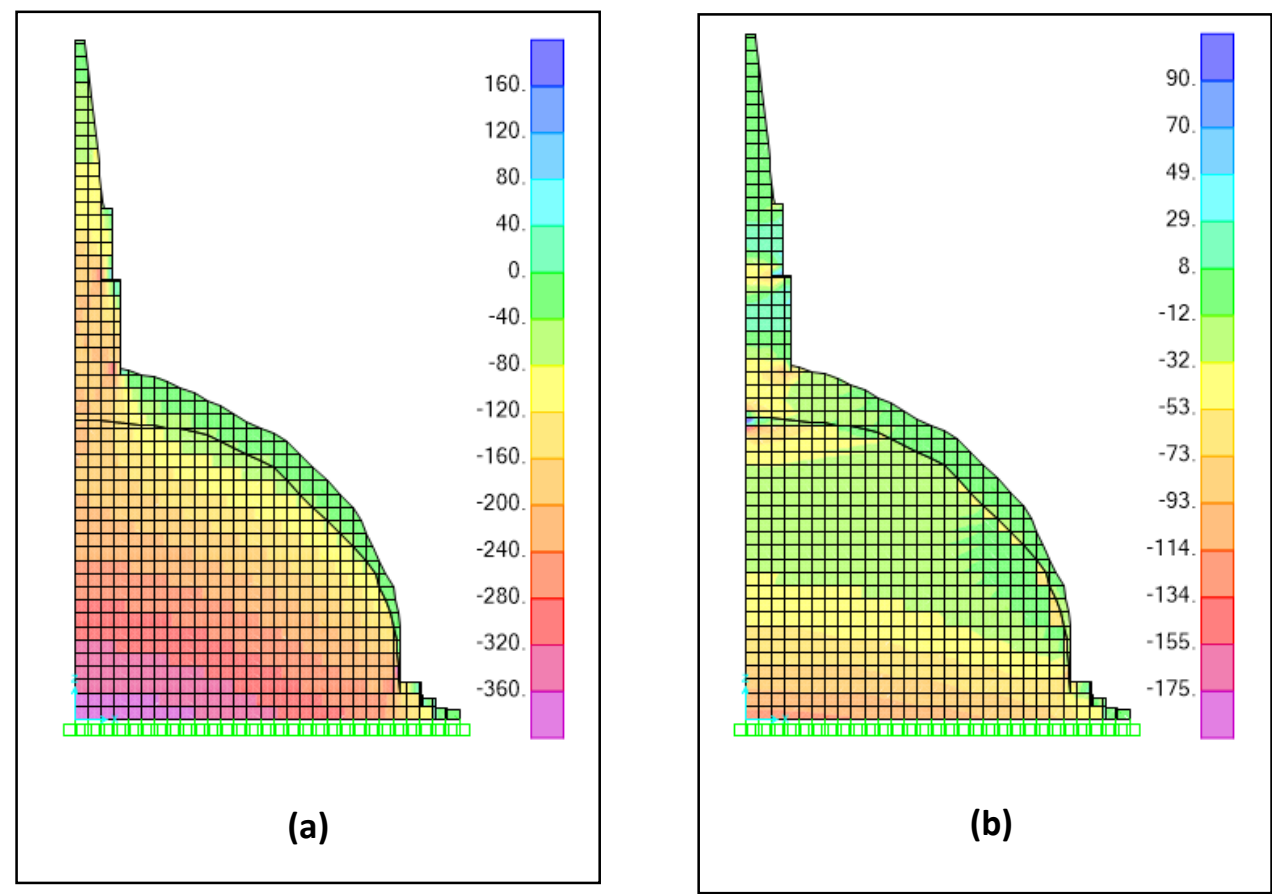

Figure 14. (a) vertical and (b) hoop stress contours $\left(\mathrm{kN} / \mathrm{m}^{2}\right)$ for the paddy heap shape model

\section{Results of the Interpretation of Finite Element Analysis}

Bubble and paddy-heap shapes are the two different shapes considered in the SAP2000 model analysis. The completed stupa with old bricks and completed stupa with new bricks have different stress distributions in the analysis. According to the analysis, the brickwork of the models is in compression and the vertical and hoop stress distributions are shown in Figures 10-14 respectively.

In each model, the stress gradually increases from the outer surface of the stupa to the center of the basal rings of the bottom plan. Maximum compressive stress can be seen at the center of the basal rings at the bottom plan.

In both shapes, the stress distribution patterns generated in the existing stupa portion after the restoration are quite similar as shown in Figures 13 and 14. The stresses of the finite element models 2 to 
5 , have been increased in considerable amounts than the stresses of the existing stupa. Finite element study showed a large region of hoop tension in the bubble shape model with old and new masonry dome (Fig. 13b). But the finite element study (Fig. 14b) showed a small region of hoop tension for the paddy-heap shape model with old and new masonry properties. The bubble shape SAP model which is reconstructed with new bricks has a maximum vertical compressive stress of $435 \mathrm{kPa}$ while paddy-heap shape has $383 \mathrm{kPa}$ as shown in Tables 8 and 9. The paddy-heap shape SAP model is selected as the most suitable shape, since its maximum vertical compressive stress is less than the bubble shape SAP model. The less height of paddyheap shape compared to the bubble shape may cause less maximum vertical compressive stress to the paddy-heap shape. The stress increases rapidly at the interfaces of the old and new brickwork.

The finite element study showed a region of hoop tension stresses in the dome induced by the self-weight. In order to identify weak zones of the stupa, finite element stress analyses were conducted and shown in Fig. 13b and Fig. 14b. When comparing the two figures, it is apparent that the paddy-heap shape stupa dome has a small tension region under self-weight, but the square chamber and the cylinders have some hoop tension. However, in the bubble-shape stupa, the hoop stress distributes in a larger region of the stupa than the paddy-heap shape stupa. In both cases, the stresses are small compared to the strength of the relevant material, thus it could be safely concluded that they do not influence in the formation of cracks.

Table 8. Comparison of results, Alternative I (Stresses of the dome)

\begin{tabular}{|c|c|c|c|c|}
\hline \multirow[t]{3}{*}{ Stresses } & \multicolumn{4}{|l|}{ Alternative I } \\
\hline & \multicolumn{2}{|l|}{$\begin{array}{l}\text { Option } 1 \\
\text { (Old brick) }\end{array}$} & \multicolumn{2}{|c|}{$\begin{array}{l}\text { Option } 2 \\
\text { (Old and new brick) }\end{array}$} \\
\hline & Compression & Tension & Compression & Tension \\
\hline $\begin{array}{l}\text { Vertical } \\
\text { stress } \\
(\mathrm{kPa})\end{array}$ & 428 & 0 & 435 & 0 \\
\hline
\end{tabular}


Table 9. Comparison of results, Alternative II (Stresses of the dome)

\begin{tabular}{lllll}
\hline Stresses & Alternative II & & \\
\cline { 2 - 5 } & $\begin{array}{l}\text { Option 1 } \\
\text { (Old brick) }\end{array}$ & \multicolumn{3}{c}{$\begin{array}{l}\text { Option 2 } \\
\text { (Old and new brick) }\end{array}$} \\
\cline { 2 - 5 } & Compression & Tension & Compression & Tension \\
\hline $\begin{array}{l}\text { Vertical } \\
\text { stress } \\
(\mathrm{kPa})\end{array}$ & 373 & 0 & 383 & 0 \\
\hline
\end{tabular}

\section{Conclusions \& Recommendations}

The existing foundation spread area and its foundation depth was checked using the Ground Penetration Radar. According to the results of the Ground Penetration Radar, the foundation of the existing Neelagiri stupa is spread around the stupa for $2.87 \mathrm{~m}$ from the basal rings and the depth is $3 \mathrm{~m}$ from the existing ground level.

In this research, different alternatives for the restoration of the Neelagiri stupa have been proposed and analyzed. Through systematic experiments (dry density, Poisson's ratio, modulus of elasticity of bricks) on the collected brick samples with an analytical investigation including the literature review, the condition assessment of the existing stupa was performed.

Four finite element models were prepared using the SAP2000 software package considering two shapes and two brick types (old and new). Self-weight of the stupa was the applied external load. These models helped to arrive at the conclusion that all stresses increase from top to bottom and a tensile or low compressive stress region could be noted at the outer surface of the dome.

The maximum vertical compressive stress is lesser if it is possible to restore the stupa using old bricks due to low value of density of old bricks. However, it is not possible to supply large amount of old bricks for the restoration. Therefore, it is decided to restore the collapsed area of Neelagiri stupa with new bricks. 
Finite element models' results showed that hoop tension stresses were induced in the dome by the self-weight. The model showed a small region of hoop tension for the paddy heap shape model with old and new masonry properties. However, those stresses are very small compared to the strength of the relevant material, thus it could be safely concluded that they do not influence in the formation of cracks. The self-weight and the shape of the stupa could be ruled out as a reason for the crack formation. Further, the shape of paddy heap is safer over the shape of the bubble for the dome of the structure as far as the stresses in the masonry are concerned. When considering the additional material usage and construction difficulties, among the two proposed superstructures, the paddy-heap shape possesses a more stable shape for the dome. However, due to the stresses generated in the exiting masonry, these two shapes could affect restoration work.

Finally, the analysis and results approached to fulfil the research aim and objectives by proposing the paddy-heap shape to be used to restore the Neelagiri stupa using new bricks. According to the alternative II, the total height of the stupa is $50.57 \mathrm{~m}$ (without the kotha).

\section{Acknowledgments}

Authors would like to acknowledge Dr. C.S. Bandara and Eng. Suranga Karunanayake of Department of Civil Engineering, University of Peradeniya for the help given during the experimental testing.

\section{References}

Dojack, L. (2012). Ground Penetrating Radar Theory, Data Collection, Processing, and Interpretation, A Guide for Archaeologists. Vancouver, University of British Columbia. DOI: $10.14288 / 1.0086065$

Gamlath, D. P. (1997). Construction Techniques and Archeology of Jethavana Stupa. Sanskruthika Puranaya, 2(8):1-10. 
Ranaweera, M. P. \& Silva, W. N. G. (2006). Conservation and Restoration of ancient stupas in Sri Lanka.The Tenth East Asia-Pacific Conference on Structural Engineering \& Construction. Bangkok.

https://www.stupa.org.nz/imagine/Ancient_Stupas_in_Sri_ Lanka.pdf

Ranaweera, M. P. (1998). Ancient stupas in Sri Lanka - Largest brick structures in the world. CHS Newsletter, 70. https://www.stupa.org.nz/imagine/CHSPaper.pdf

Silva, W. N. G. (2002). Conservation of Ancient Dagobas in Sri Lanka. Constructor, 7(2):73-77.

Somadeva, R. (2012). The Archaeological Survey in Neelagiri stupa Area in Lahugala of Ampara District. Colombo, Postgraduate Institute of Archaeology. https://www.archaeology.lk/ 1484 